\title{
Kadar Vitamin E Rendah Sebagai Faktor Risiko Peningkatan Bilirubin Serum pada Neonatus
}

\author{
Tun Paksi Sareharto, * Kamilah Budhi $R$, * Noor Wijayahadi** \\ * Bagian Ilmu Kesehatan Anak FK Universitas Diponegoro/RSUP Dr. Kariadi Semarang \\ ** Bagian Farmakologi FK Universitas Diponegoro/RSUP Dr. Kariadi Semarang
}

\begin{abstract}
Latar belakang. Hiperbilirubinemia terjadi pada 25\%-50\% bayi baru lahir (BBL) dapat menurunkan kualitas hidup. Secara fisiologis bilirubin meningkat mencapai puncak pada kadar 5-6 mg/dL pada hari ke 3-4 kehidupan, terbanyak karena hemolisis (75\%) yang kemungkinan terjadi akibat paparan oksidan. Vitamin E melindungi membran eritrosit dari kerusakan oksidatif, sedangkan vitamin $\mathrm{C}$ membantu regenerasi sel untuk dapat berfungsi kembali.

Tujuan. Menganalisis kadar vitamin E dengan memperhatikan kadar vitamin $\mathrm{C}$ serum yang rendah sebagai faktor risiko peningkatan kadar bilirubin serum yang patologis pada neonatus.

Metode. Desain penelitian adalah nested case control dengan subjek 80 neonatus aterm sehat di RSUP Dr. Kariadi pada Maret-Mei 2009, 40 neonatus sebagai kasus dan 40 neonatus sebagai kontrol. Kadar bilirubin diperiksa hari ke 3-4, kadar vitamin E dan vitamin C diperiksa dari sampel darah hari pertma setelah lahir. Faktor risiko dianalisis dengan rasio odds (95\% interval kepercayaan) dan regresi logistik.

Hasil. Subjek 40 neonatus aterm sehat dengan kadar bilirubin $\geq 5 \mathrm{mg} / \mathrm{dL}$ sebagai kasus dan 40 neonatus dengan kadar bilirubin $<5 \mathrm{mg} / \mathrm{dL}$ sebagai kontrol. Rerata bilirubin total (mg/dL): 9,69 $\pm 2,41$ (kasus),

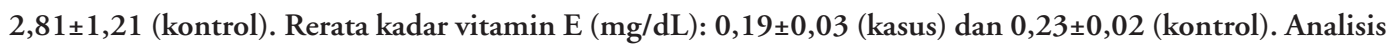
bivariat menunjukan kadar vitamin $\mathrm{E}$ rendah merupakan faktor risiko terjadinya peningkatan kadar bilirubin $(\mathrm{OR}=23,7 ; 95 \% \mathrm{CI}$ 6,8-82,4). Analisis multivariat menunjukkan kadar vitamin $\mathrm{E}$ dan vitamin $\mathrm{C}$ rendah mempunyai faktor risiko yang lebih tinggi terhadap peningkatan kadar bilirubin (OR=55,9; 95\%CI 6,7467,7).
\end{abstract}

Kesimpulan. Kadar vitamin $\mathrm{E}$ dan vitamin $\mathrm{C}$ rendah merupakan faktor risiko peningkatan kadar bilirubin pada neonatus. (Sari Pediatri 2010;11(5):355-62).

Kata kunci: vitamin E rendah, faktor risiko, bilirubin serum, neonatus.

\footnotetext{
Alamat korespondensi:

Dr. Kamilah Budi Rahardjani, Sp.A(K). Bagian IKA FK-UNDIP/RS Dr. Kariadi Semarang Jawa Tengah. Telp. 024 - 8414296, Fax. 024 8318617.
}

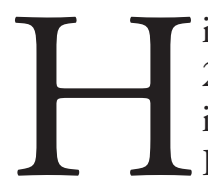

iperbilirubinemia dapat terjadi pada $25 \%-50 \%$ bayi baru lahir (BBL) dari ibu dengan berbagai usia kehamilan. ${ }^{1}$ Di Indonesia, insiden ikterus pada bayi cukup bulan (BCB) di beberapa rumah sakit pendidikan antara lain RS Dr. Cipto Mangunkusumo, RS 
Dr. Sardjito, RS Dr. Soetomo, dan RS Dr. Kariadi bervariasi dari 13,7\% hingga 85\%. Data dari RS Dr. Kariadi tahun 2003 mendapatkan insiden ikterus neonatorum $12 \%$ pada BCB, 78\% merupakan ikterus fisiologis. Kasus kematian BBL terkait dengan hiperbilirubinemia terhadap seluruh BBL yang dirawat pada tahun 2003 di RS Dr. Sardjito Yogyakarta 24\% dan di RS Dr. Kariadi Semarang 13,1\%. ${ }^{2}$ Hiperbilirubinemia dapat mengakibatkan kerusakan otak pada neonatus yang mampu bertahan hidup yang pada akhirnya dapat menurunkan kualitas hidup anak. ${ }^{3,4}$

Kadar bilirubin bayi baru lahir dipengaruhi oleh usia kehamilan, berat lahir dan asupan ASI, serta apabila terdapat inkompatibilitas golongan darah, abnormalitas struktur eritrosit, dan defisiensi enzim G6PD. ${ }^{5,6}$ Hiperbilirubinemia sebagian besar merupakan bilirubin fisiologis umumnya meningkat sampai melebihi $2 \mathrm{mg} / \mathrm{dL}$ pada hari-hari pertama kehidupan, ${ }^{1,6}$ mencapai puncak rata-rata pada kadar 5-6 mg/dL pada hari ke 3-4 dan kemudian menurun setelah usia satu minggu pada bayi cukup bulan., ${ }^{7,8}$

Bilirubin pada neonatus sebagian besar berasal dari pemecahan hemoglobin akibat hemolisis sehingga bilirubin dapat dipakai sebagai petunjuk adanya hemolisis. ${ }^{3,9}$ Kadar bilirubin pada neonatus meningkat disebabkan karena lisis eritrosit akibat besarnya jumlah eritrosit pada awal kehidupan dan siklus pergantian eritrosit yang cepat, umur hidup eritrosit yang lebih pendek yaitu 80 hari dibandingkan pada usia dewasa yang 120 hari. ${ }^{10}$ Bilirubin indirek dapat melewati sawar darah otak, bersifat toksik terhadap sel otak berdampak pada neuropatologi/kerusakan otak sehingga menetap dan terjadi kern icterus (ensefalopati bilirubin), berisiko mengalami kematian. Neonatus yang dapat bertahan hidup dapat mengalami gejala sisa berupa palsi serebral, gangguan pendengaran, paralisis, dan displasia dental, sehingga berdampak pada penurunan kualitas hidup anak. ${ }^{3,4,10}$

Eritrosit neonatus relatif sensitif terhadap oksidan dibandingkan eritrosit anak mengakibatkan mudah terjadi kerusakan oksidatif. Hal ini terjadi karena masih kurangnya kemampuan kapasitas eritrosit neonatus terhadap stres oksidatif sebagai akibat kurangnya pertahanan antioksidan terutama pada bayi prematur. ${ }^{11,12}$ Oksidan, sebagian berbentuk radikal bebas, dihasilkan selama proses metabolisme pada sebagian besar sel tubuh termasuk eritrosit. ${ }^{13,14,15} \mathrm{Tu}$ buh menghasilkan antioksidan yang efisien terhadap kerusakan oksidatif, yaitu beberapa enzim termasuk katalase, superoksidase dismutase, glutation peroksidase, dan antioksidan non enzim seperti glutation, dan vitamin E. ${ }^{16}$ Pembentukan oksidan/radikal bebas yang melebihi antioxidant defences capacity menyebabkan kerusakan oksidatif, mengganggu integritas komponen fosfolipid penyusun membran sel, deoxyribonucleic acid (DNA), dan protein sel, terjadi peroksidasi lipid yang berakibat hemolisis. ${ }^{13}$ Eritrosit pada neonatus berumur pendek dengan jumlah yang besar dan rentan terhadap paparan oksidan sehingga mudah terjadi hemolisis. Beberapa hal inilah yang memudahkan terjadinya peningkatan kadar bilirubin. ${ }^{10-12}$

Vitamin E, suatu antioksidan poten yang melindungi membran sel terhadap kerusakan oksidatif yang mengakibatkan lisis sel, ${ }^{17}$ mencegah terjadinya hemolisis, yang kemudian mencegah hiperbilirubinemia pada neonatus. ${ }^{18}$ Dalam menjalankan fungsinya, vitamin $\mathrm{E}$ yang telah teroksidasi mengalami regenerasi kembali dibantu oleh vitamin C. ${ }^{19,20}$

Penelitian bertujuan menganalisis kadar vitamin E serum yang rendah dengan memperhitungkan kadar vitamin $C$ serum yang rendah, terhadap kejadian peningkatan kadar bilirubin serum pada neonatus.

\section{Metode}

Desain penelitian nested case control dengan subjek neonatus sehat yang dirawat di ruang Rawat Gabung RSUP Dr. Kariadi Semarang periode Maret-Mei 2009. Neonatus sehat adalah neonatus dengan kondisi aktif, gerakan simetris, tangis serta minum kuat, napas spontan dan teratur, berat lahir 2500-4000 gram, skor Apgar pada menit pertama lebih dari tujuh, dan tidak terdapat kelainan bawaan berat/mayor. Subjek penelitian harus memenuhi kriteria neonatus sehat selama pengamatan, lahir cukup bulan, kadar bilirubin serum hari pertama kurang dari $5 \mathrm{mg} / \mathrm{dL}$, serta mendapat persetujuan orang tua/wali untuk ikut dalam penelitian. Neonatus tidak dimasukkan dalam penelitian apabila terdapat abnormalitas struktur eritrosit (kelainan eritrosit herediter), inkompatibilitas golongan darah, defisiensi enzim G6PD, dan mendapat minum selain ASI. Neonatus dimasukkan ke dalam kelompok kasus apabila memenuhi kriteria inklusi dan eksklusi dengan kadar bilirubin total serum hari ke 3-4 sama atau lebih dari $5 \mathrm{mg} / \mathrm{dL}$, sedangkan kelompok kontrol apabila memenuhi kriteria inklusi dan eksklusi dengan kadar bilirubin total serum hari ke 3-4 kurang 
dari $5 \mathrm{mg} / \mathrm{dL}$. Pengambilan sampel dilakukan dengan consecutive sampling.

Besar sampel dihitung dengan rumus besar sampel penelitian kasus kontrol, tingkat kemaknaan $\alpha 5 \%$ dan power $80 \%$. Nilai odd ratio (OR) untuk kejadian hiperbilirubinemia ditentukan berdasarkan penelitian oleh Perales B dkk9 mengenai perubahan dalam deformabilitas eritrosit dan viskositas plasma pada neonatus dengan ikterus 4,3. Setelah diperhitungkan dengan koreksi drop out, didapatkan besar sampel minimal 40 neonatus per kelompok.

Tahapan penelitian dimulai dari bayi baru lahir masuk dirawat di ruang Rawat Gabung RSUP Dr. Kariadi. Pertama kali dilakukan pemeriksaan untuk menentukan subjek penelitian yaitu neonatus aterm sehat, lahir cukup bulan dengan kondisi aktif, gerakan simetris, tangis dan minum kuat, napas spontan dan teratur, berat lahir 2500-4000 gram, skor Apgar pada menit pertama $>7$, tidak terdapat kelainan bawaan berat/mayor. ${ }^{21}$ Informed consent dilakukan kemudian kepada orang tua/wali. Hanya neonatus yang mendapat persetujuan saja yang disertakan dalam penelitian. Selanjutnya dilakukan pengambilan darah vena dalam rentang 24 jam pertama setelah lahir, untuk pemeriksaan-pemeriksaan kadar hemoglobin, hematokrit, jumlah leukosit, gambaran darah tepi untuk melihat kelainan struktur eritrosit, bilirubin total (indirek), enzim G6PD, dan uji Coomb. Sebagian sampel darah disimpan untuk pemeriksaan kadar vitamin E dan C. Perawatan hari ke 3-4 dilakukan pengambilan sampel darah vena kedua, untuk pemeriksaan bilirubin.

Sampel dikelompokkan berdasarkan kadar bilirubin pemeriksaan hari ke-3-4. Kadar bilirubin $\geq 5$ $\mathrm{mg} / \mathrm{dL}$ dimasukkan kelompok kasus. Sampel dengan kadar bilirubin $<5 \mathrm{mg} / \mathrm{dL}$ sebagai kelompok kontrol. Variabel yang diteliti adalah kadar bilirubin total serum pada hari ke 3 atau 4 kehidupan, serta kadar vitamin E dan vitamin $C$ serum pada hari pertama kehidupan. Pengukuran kadar vitamin E menggunakan metoda Elisa (Immunoassay), vitamin C menggunakan metoda Colorimetric Assay, dan bilirubin total menggunakan metoda Bichromatic modifikasi prosedur Jendrassik dan Grof.

Kadar bilirubin meningkat apabila kadar bilirubin total lebih dari atau sama dengan $5 \mathrm{mg} / \mathrm{dL}$. Kadar vitamin E menurun apabila kurang dari $0,22 \mathrm{mg} / \mathrm{dL}$ dan vitamin $C$ kurang dari $7 \mu \mathrm{g} / \mathrm{mL}$. Faktor risiko vitamin $\mathrm{E}$ dianalisis dengan uji bivariat chi-square, dan pengaruh vitamin $\mathrm{C}$ dianalisis dengan uji multivariat regresi logistik. Variabel dinyatakan sebagai faktor risiko apabila nilai $\mathrm{OR}>1$ dan dinyatakan sebagai faktor protektif apabila $\mathrm{OR}<1$. Penilaian faktor risiko juga berdasarkan rentang interval kepercayaan 95\% (95\%

Tabel 1. Karakteristik subjek

\begin{tabular}{|c|c|c|c|}
\hline \multirow[b]{2}{*}{ Variabel } & \multicolumn{2}{|c|}{ Kelompok kadar bilirubin } & \multirow[b]{2}{*}{$\mathrm{p}$} \\
\hline & $\begin{array}{c}\text { Kasus }(\geq 5 \mathrm{mg} / \mathrm{dL}) \\
\mathrm{n}=40\end{array}$ & $\begin{array}{c}\text { Kontrol }(<5 \mathrm{mg} / \mathrm{dL}) \\
\mathrm{n}=40\end{array}$ & \\
\hline Umur ibu (tahun) & $29,15 \pm 6,50$ & $28,98 \pm 7,95$ & $0,832^{*}$ \\
\hline Usia kehamilan (minggu) & $39,10 \pm 1,34$ & $39,13 \pm 1,38$ & $0,830^{*}$ \\
\hline Cara partus $(\%)$ & & & $0,125^{*}$ \\
\hline - Spontan & $18(45)$ & $20(50)$ & \\
\hline - Sectio caesaria & $13(32,5)$ & $17(42,5)$ & \\
\hline - Ekstraksi vakum & $7(17,5)$ & $3(7,5)$ & \\
\hline - Ekstraksi bokong & $2(5)$ & $0(0)$ & \\
\hline Lama partus (jam) & $3,92 \pm 3,54$ & $5,65 \pm 9,57$ & $0,458^{*}$ \\
\hline Berat lahir (gram) & $2900 \pm 332,0$ & $2986,2 \pm 394,0$ & $0,354^{*}$ \\
\hline Jenis kelamin bayi (\%) & & & $0,502^{£}$ \\
\hline - Laki-laki & $23(57,5)$ & $19(47,5)$ & \\
\hline - Perempuan & $17(42,5)$ & $21(52,5)$ & \\
\hline Kadar bilirubin total $(\mathrm{mg} / \mathrm{dL})^{* *}$ & $9,69 \pm 2,41$ & $2,81 \pm 1,21$ & $0,001 *$ \\
\hline Kadar vitamin $\mathrm{E}(\mathrm{mg} / \mathrm{dL})^{* *}$ & $0,19 \pm 0,03$ & $0,23 \pm 0,02$ & $0,001 *$ \\
\hline Kadar vitamin $C(\mu \mathrm{g} / \mathrm{mL})^{* *}$ & $6,90 \pm 0,10$ & $7,18 \pm 0,27$ & $0,001^{*}$ \\
\hline
\end{tabular}

* Uji Mann-Whitney $\quad{ }^{£}$ Uji Fisher

$¥$ Uji Kolmogorov-Smirnov

${ }^{* *}$ Rerata (simpang baku) atau n (\%). 
confidence interval $=\mathrm{CI})$. Apabila rentang nilai $95 \%$ CI melingkupi angka 1 maka variabel tersebut belum dapat disimpulkan sebagai faktor risiko (inconclusive). Nilai $p$ dianggap bermakna apabila $p<0,05$ dengan 95\% interval kepercayaan. Analisis statistik menggunakan program SPSS for Windows versi 15. Penelitian telah mendapat persetujuan Komite Etik Penelitian Kesehatan Fakultas Kedokteran Universitas Diponegoro/RSUP Dr. Kariadi Semarang.

\section{Hasil}

Dari 548 neonatus yang dirawat di ruang rawat gabung pada periode penelitian didapatkan 265 neonatus yang memenuhi kriteria inklusi, 169 tidak dapat ikut penelitian, dan 16 neonatus drop out, sehingga 80 neonatus sebagai subjek penelitian. Subjek dibagi dua kelompok dengan jumlah yang sama, kasus dan kontrol berdasarkan kadar bilirubin lebih dari atau sama dengan $5 \mathrm{mg} / \mathrm{dL}$ dan kurang dari $5 \mathrm{mg} / \mathrm{dL}$.

Dari Tabel 2, tampak tidak ada hubungan bermakna secara statistik antara kadar bilirubin dengan usia ibu, usia kehamilan, cara partus, lama partus, berat lahir, dan jenis kelamin. Kadar bilirubin total, vitamin $\mathrm{E}$ dan $\mathrm{C}$ menunjukkan perbedaan bermakna secara statistik.
Terdapat hubungan bermakna secara, antara kadar vitamin E terhadap bilirubin. Kadar vitamin E yang rendah mempunyai risiko 23,7 kali lebih besar terjadi peningkatan kadar bilirubin dibanding kadar vitamin E normal.

Kadar vitamin E rendah disertai kadar vitamin $\mathrm{C}$ rendah mempunyai risiko untuk mengalami peningkatan kadar bilirubin 55,9 kali lebih besar dibandingkan dengan kadar vitamin $\mathrm{E}$ dan $\mathrm{C}$ normal.

\section{Diskusi}

Beberapa karakteristik variabel pada penelitian ini seperti jenis kelamin bayi, usia ibu, pendidikan dan pekerjaan ibu, serta cara dan lama partus menunjukkan tidak ada perbedaan yang bermakna terhadap peningkatan kadar bilirubin serum. Hal ini sesuai dengan pendapat para ahli selama ini yang menyebutkan bahwa hal-hal tersebut di atas tidak pernah dikemukakan mempunyai hubungan dengan kadar bilirubin dan tidak ada perdebatan mengenai hal tersebut. ${ }^{1,5,22}$

Sampel penelitian ini diambil dari neonatus dengan kondisi yang sama, yaitu masa kehamilan yang cukup bulan dan berat lahir yang normal sesuai

Tabel 2. Tabulasi silang antara kelompok kadar vitamin E terhadap kelompok kasus dan kontrol

\begin{tabular}{|c|c|c|c|c|}
\hline \multirow[b]{2}{*}{ Kadar vitamin E } & \multicolumn{2}{|c|}{ Kelompok } & \multirow[b]{2}{*}{ OR $(95 \% \mathrm{CI})$} & \multirow[b]{2}{*}{$\mathrm{p}$} \\
\hline & $\begin{array}{l}\text { Kasus } \\
\mathrm{n}=40\end{array}$ & $\begin{array}{c}\text { Kontrol } \\
\mathrm{n}=40\end{array}$ & & \\
\hline$<0,22 \mathrm{mg} / \mathrm{dL}(\%)$ & $29(72,5)$ & $4(10,0)$ & $23,7(6,8-82,4)$ & $0,001 \$$ \\
\hline$\geq 0,22 \mathrm{mg} / \mathrm{dL}(\%)$ & $11(27,5)$ & $36(90,0)$ & & \\
\hline
\end{tabular}

* Kadar vitamin E normal pada neonatus $\geq 0,22 \mathrm{mg} / \mathrm{dL}$

${ }^{\S}$ Uji chi square

Tabel 3. Hasil analisis multivariat regresi logistik

\begin{tabular}{cccccccc}
\hline \multirow{2}{*}{ Faktor risiko } & & \multicolumn{2}{c}{ Kelompok } & \multicolumn{2}{c}{ Crude } \\
OR & Adjusted OR (95\% CI) & p \\
\cline { 2 - 4 } & & Kasus & Kontrol & & & \\
Vitamin E & $<0,22$ & 29 & 4 & 23,7 & $55,9(6,7-467,7)$ & 0,001 \\
$(\mathrm{mg} / \mathrm{dL})$ & $\geq 0,22^{*}$ & 11 & 36 & 1 & 1 & - \\
Vitamin C & $<7$ & 36 & 14 & 16,7 & $42,1(4,8-369,5)$ & 0,001 \\
$(\mu \mathrm{g} / \mathrm{mL})$ & $\geq 7^{*}$ & 4 & 26 & 1 & 1 & - \\
\hline
\end{tabular}

\footnotetext{
* Kadar vitamin E normal pada neonatus

* Kadar vitamin C normal pada neonatus
} 
masa kehamilan sehingga tidak terdapat perbedaan yang bermaka terhadap peningkatan kadar bilirubin. Hal ini sesuai dengan penelitian yang dilakukan oleh Abdul-Razzak KK dkk ${ }^{23}$ mengenai hubungan antara kadar vitamin $\mathrm{E}$ dan vitamin $\mathrm{C}$ plasma terhadap tingkat keparahan hiperbilirubinemia pada 130 neonatus sehat dari ibu sehat yang mengemukakan bahwa usia kehamilan yang cukup bulan dan berat lahir normal menunjukkan tidak adanya perbedaan yang bermakna terhadap peningkatan kadar bilirubin.

Rerata kadar vitamin E dan vitamin C pada kelompok kasus lebih kecil dibandingkan dengan kelompok kontrol. Pendapat kami tersebut sama dengan penelitian Abdul-Razzak KK dkk ${ }^{23}$ mengemukakan hal yang sama. Pada penelitian mereka didapatkan bahwa rerata kadar vitamin $\mathrm{E}$ dan vitamin $\mathrm{C}$ plasma di hari pertama kehidupan pada neonatus yang mengalami hiperbilirubinemia mempunyai kadar yang lebih rendah dibandingkan dengan neonatus yang tidak mengalami hiperbilirubinemia. ${ }^{23}$ Demikian pula Mohan SK $\mathrm{dkk}^{24}$ mendapatkan temuan yang sama bahwa kadar vitamin $\mathrm{E}$ dan vitamin $\mathrm{C}$ pada neonatus yang mengalami ikterus mempunyai kadar yang lebih rendah dibandingkan neonatus yang tidak mengalami ikterus. Ini menunjukkan bahwa antioksidan, yaitu vitamin $\mathrm{E}$ dan vitamin $\mathrm{C}$, mempunyai kadar rendah pada neonatus yang mengalami hiperbilirubinemia.

Ojo CO $\mathrm{dkk}^{18}$ juga mendapatkan kadar vitamin E plasma berhubungan dengan kadar bilirubin dan kejadian hemolisis pada neonatus. Neonatus dengan ikterus mengalami penurunan kadar vitamin $\mathrm{E}$ dan peningkatan kejadian hemolisis yang bermakna. Terdapat korelasi yang negatif antara kadar vitamin E dan bilirubin serta kadar vitamin E dan hemolisis, berarti bahwa penurunan kadar vitamin E dapat meningkatkan kadar bilirubin dan kejadian hemolisis. Temuan hasil penelitian tersebut menunjukkan bahwa hemolisis dan hiperbilirubinemia yang terjadi pada neonatus dengan ikterus dapat terjadi karena kekurangan vitamin E.

Peningkatan kadar bilirubin pada neonatus sebagian besar merupakan akibat dari adanya hemolisis.,25 Oksidan kuat dapat mengganggu integritas sel, khususnya yang mengandung asam lemak tak jenuh yang merupakan komponen fosfolipid penyusun membran sel, DNA dan protein sel. Pembentukan oksidan/radikal bebas yang melebihi antioxidant defense capacity menyebabkan stres oksidatif atau peningkatan produksi spesies oksigen reaktif (SOR) yang berdampak kerusakan organ yang rentan seperti lipid membran sel, asam amino penyusun protein enzim, dan DNA. ${ }^{13,15}$ Stres oksidatif lebih mudah terjadi pada neonatus dibandingkan pada anak karena kemampuan kapasitas eritrosit neonatus sebagai pertahanan antioksidan masih rendah. Stres oksidatif yang mengenai eritrosit berdampak timbulnya peroksidasi lipid pada membran sel eritrosit mengakibatkan hemolisis lebih banyak terjadi pada neonatus dibandingkan pada anak. ${ }^{13,17,26}$ Eritrosit neonatus rentan terhadap stres oksidatif yang berdampak terjadinya peroksidasi lipid pada membran sel eritrosit sehingga terjadi hemolisis. ${ }^{17,26}$

Peningkatan petanda stres oksidatif dan penurunan pertahanan antioksidan dalam plasma berkaitan dengan tingginya hemolisis neonatus pada saat awal kelahiran terutama pada neonatus prematur. ${ }^{27,28}$ Dani $\mathrm{C} \mathrm{dkk}^{29}$ mengemukakan bahwa penurunan kadar bilirubin plasma sesuai dengan peningkatan kapasitas antioksidan dan penurunan stres oksidatif pada neonatus prematur. Pada penelitian yang dilakukan oleh Mohan SK dan Priya $\mathrm{P}^{24}$ mendapatkan neonatus dengan ikterus mempunyai kadar Malondialdehyde (MDA) yang meningkat, terdapat aktifitas superoksida dismutase (SOD) dan glutation peroksidase (GPx), kadar glutation (GSH), vitamin C, vitamin E plasma, dan aktivitas katalase yang menurun secara signifikan dibandingkan dengan neonatus yang tidak mengalami ikterus. Peningkatan aktifitas antioksidan enzim merupakan respon kompensasi terhadap peningkatan stres oksidatif. Penurunan kadar glutation dan antioksidan vitamin menyokong hipotesis bahwa ikterus pada neonatus merupakan faktor penyebab penting dalam patogenesis peroksidasi lipid, dan mekanisme pertahanan antioksidan dapat menurun pada neonatus dengan ikterus. Hasil penelitian tersebut menunjukkan stres oksidatif lebih banyak terjadi pada neonatus yang mengalami ikterus. Vitamin E dan vitamin $\mathrm{C}$ merupakan antioksidan kuat pada tingkat selular, memainkan peran penting dalam perlindungan sel terhadap kerusakan oksidatif dan hemolisis, sehingga kadar vitamin E dan vitamin C berkaitan dengan hiperbilirubinemia pada neonatus yang cenderung patologis. ${ }^{17,29}$

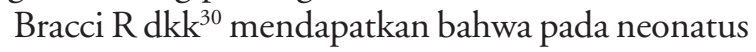
yang memiliki kadar bilirubin melebihi $214 \mathrm{mmol} / \mathrm{L}$ $(12,5 \mathrm{mg} / \mathrm{dL})$ mempunyai aktifitas antioksidan enzim (GPx dan SOD) yang rendah pada saat lahir dibandingkan neonatus dengan kadar bilirubin lebih rendah. Kadar antioksidan tersebut berkorelasi 
negatif dengan kadar puncak bilirubin pada saat lahir. Dikatakan bahwa defisiensi antioksidan berperan terhadap terjadinya hemolisis dan ikterus pada neonatus. Meskipun Bracci $\mathrm{R} \mathrm{dkk}{ }^{30}$ tidak meneliti mengenai antioksidan vitamin (vitamin $\mathrm{E}$ maupun vitamin C) namun hasil yang didapatkan tersebut secara tidak langsung menggambarkan antioksidan rendah berhubungan dengan timbulnya ikterus pada neonatus.

Vitamin E merupakan antioksidan pemutus rantai peroksidasi lipid yang larut dalam lemak berada dalam membran sel eritrosit bekerja lebih efektif dalam menekan hemolisis dibandingkan dengan vitamin C. Vitamin C merupakan antioksidan yang efektif bekerja dalam plasma sel untuk menekan hemolisis karena sifatnya yang larut dalam air. ${ }^{31,32}$

Pada penelitian kami didapatkan bahwa peran antioksidan vitamin $\mathrm{E}$ juga dipengaruhi oleh vitamin $\mathrm{C}$, risiko terjadi peningkatan kadar bilirubin menjadi lebih besar apabila kedua vitamin ini dalam kadar yang rendah, sehingga diasumsi kedua vitamin tersebut bekerja bersama dalam mencegah terjadi hemolisis dan peningkatan kadar bilirubin. Penelitian yang dilakukan oleh Niki E $\mathrm{dkk}^{32}$ menunjukkan adanya dampak sinergis antara vitamin $\mathrm{E}$ dan vitamin C dalam menghambat peroksidasi lipid. Vitamin $\mathrm{C}$ membantu dalam regenerasi vitamin $\mathrm{E}$ sebagaimana vitamin $\mathrm{E}$ teroksidasi oleh radikal bebas dalam membran lipid. Kesimpulan dari penelitian Niki dkk bahwa kadar vitamin $\mathrm{E}$ dan vitamin $\mathrm{C}$ plasma yang rendah terkait dengan hiperbilirubinemia pada neonatus karena peningkatan stres oksidatif dan hemolisis.

Hubungan sinergistik antara vitamin $\mathrm{E}$ dan vitamin C juga ditunjukkan oleh Strain JJ dkk. ${ }^{33}$ Penelitian secara in vitro yang mereka lakukan menunjukkan bahwa kedua vitamin tersebut dapat mencegah terjadinya peroksidasi lipid. Adanya kemampuan vitamin $\mathrm{C}$ dalam bereaksi terhadap radikal tokoferoksil yang timbul, dapat mengubah radikal $\alpha$-tokoferoksil kembali menjadi $\alpha$-tokoferol aktif. 33,34

Penelitian yang dilakukan oleh Niki E dkk ${ }^{32}$ serta Strain JJ $\mathrm{dkk}^{33}$ menunjukkan adanya efek sinergis antara vitamin $\mathrm{E}$ dan vitamin $\mathrm{C}$ dalam mencegah hemolisis yang pada akhirnya mencegah terjadinya hiperbilirubinemia. Vitamin C membantu dalam regenerasi vitamin E sebagaimana vitamin E teroksidasi oleh radikal bebas dalam lapisan lipid. Kedua hasil penelitian tersebut dapat disimpulkan bahwa kadar vitamin $\mathrm{E}$ dan vitamin $\mathrm{C}$ yang rendah terkait secara signifikan dengan hiperbilirubinemia pada neonatus karena peningkatan stres oksidatif dan hemolisis. ${ }^{34}$

Keterbatasan penelitian ini adalah tidak memperhitungkan variabel antioksidan/oksidan/radikal bebas lain yang dapat mempengaruhi kejadian hemolisis atau peningkatan kadar bilirubin pada neonatus, misalnya SOD, katalase, glutation peroksidase, dan glutation reduktase. Tidak pula memperhitungkan variabel lain yang dapat mempengaruhi peningkatan kadar bilirubin serum, misalnya kelainan transportasi bilirubin, gangguan ambilan hati, kelainan metabolik dan defek biokimia.

Dari penelitian kami disimpulkan, terdapat hubungan antara kadar vitamin E serum yang rendah terhadap kejadian peningkatan kadar bilirubin serum yang cenderung patologis pada neonatus. Kadar vitamin E serum rendah menjadi faktor risiko kejadian peningkatan kadar bilirubin, demikian pula dengan memperhitungkan kadar vitamin $\mathrm{C}$ serum yang rendah.

\section{Saran}

Perlu dilakukan penelitian lebih lanjut terhadap pengaruh pemberian vitamin E pada bayi baru lahir terhadap kejadian peningkatan kadar bilirubin, keterlibatan variabel antioksidan dan oksidan/radikal bebas lain yang mempengaruhi kejadian hemolisis seperti SOD, katalase, glutation peroksidase, serta glutation reduktase. Serta keterlibatan kejadian lain yang mempengaruhi peningkatan kadar bilirubin pada neonatus seperti kelainan transportasi bilirubin, gangguan ambilan hati, kelainan metabolik, dan defek biokimia.

\section{Daftar Pustaka}

1. Martin CR, Cloherty JP. Neonatal hiperbilirubinemia. Dalam: Cloherty JP, Eichenwald EC, Stark AR, penyunting. Manual of neonatal care. Edisi ke-5. Philadelphia: Lippincott Williams \& Wilkins; 2004.h.185-221.

2. Unit Pengkajian Teknologi Kesehatan Direktorat Jenderal Pelayanan Medik Departemen Kesehatan Republik Indonesia. Tata laksana ikterus neonatorum. HTA Indonesia, Dirjen Yanmed Depkes RI 2004;1:1-22.

3. Dennery PA, Seidman DS, Stevenson DK. Neonatal 
hyperbilirubinemia. N Engl J Med 2001;344:581-90.

4. Connolly AM, Volpe JJ. Clinical features of bilirubin encephalopathy. Clin Perinatol 1990;17:371-9.

5. Sukadi A. Hiperbilirubinemia. Dalam: Kosim MS, Yunanto A, Dewi R, Sarosa GI, Usman A, penyunting. Buku ajar neonatologi. Edisi pertama. Jakarta: Badan Penerbit Ikatan Dokter Anak Indonesia; 2008.h.14769.

6. Uy CC. Hyperbilirubinemia, indirect (unconjugated hyperbilirubinemia). Dalam: Gomella TL, Cunningham MD, Eyal FG, Zenk KE. Neonatology: management, procedures, on-call problems, diseases, and drugs. Edisi ke-6. New York: Lange Medical Book/McGraw-Hill; 2009. p. 498-510.

7. Gilmore MM. Hyperbilirubinemia, indirect (unconjugated hyperbilirubin-emia). Dalam: Gomella TL, Cunningham MD, Eyal FG, Zenk KE, penyunting. Neonatology: management, procedures, on-call problems, diseases, and drugs. Edisi ke-6. New York: Lange Medical Book/McGraw-Hill; 2009.h.293-301.

8. Porter ML, Dennis BL. Hyperbilirubinemia in the term newborn. Am Fam Phys 2002;65:599-606.

9. Perales B, Hoyos M, Morales M, Carballo M, Fernandez U, Prieto P. Changes in erythrocytic deformability and plasma viscosity in neonatal ictericia. Am J Perinatol 1999; 16:421-7.

10. Halamek LP, Stevenson DK. Neonatal jaundice and liver disease. Dalam: Neonatal-perinatal medicine: diseases of the fetus and infant, Edisi ke-6. New York: Mosby-Year Book Inc; 1997.h.1345-62.

11. Gross RT, Bracci R, Rudolph N, Schroeder E, Kochen JA. Hydrogen peroxide toxicity and detoxification in the erythrocytes of newborn infants. Blood 1967;29:48193.

12. Kilic M, Turgut M, Taskin E, Cekmen M, Aygun AD. Nitric oxide levels and antioxidant enzyme activities in jaundices of premature infants. Cell Biochem Funct 2004;22:339-42.

13. Langseth L. Oxidants and antioxidants: some basic concepts. Dalam: Bracco U, Jardine NJ, penyunting. Oxidants, antioxidants, and disease prevention. Belgium: International Life Science Institute; 1994.h.1-4.

14. Suryohudoyo P. Oksidan, antioksidan dan radikal bebas. Dalam: Suryohudoyo P. Kapita selekta ilmu kedokteran molekuler. Jakarta: CV Sagung Seto; 2000.h.31-47.

15. Segel GB. Definitions and classification of hemolytic anemias. Dalam: Behrman RF, Kliegman RM, Jenson $\mathrm{HB}$, penyunting. Nelson textbook of pediatrics. Edisi ke17. Philadelphia: WB Saunders Co; 2004.h.1617-9.
16. Dani C, Cecchi A, Bertini G. Role of oxidative stress as physiopathologic factor in the preterm infant. Minerva Pediatr 2004;56:381-94.

17. Vanderpas J, Vertongen F. Erythrocyte vitamin E is oxidized at a lower peroxide concentration in neonates than in adults. Blood 1985;66:1272-7.

18. Ojo CO, Dawodu AH, Osifo BO. Vitamin E deficiency in the pathogenesis of haemolysis and hyperbilirubinaemia of neonatal jaundice. J Trop Pediatr 1986;32:251-4.

19. Padayatty SJ, Katz A, Wang Y, Eck P, Kwon O, Lee JH, dkk. Vitamin C as an antioxidant: evaluation of its role in disease prevention. J Am College Nutr 2003;22:18-35.

20. Wen Y, Cooke T, Feely J. The effect of pharmacological supplementation with vitamin $\mathrm{C}$ on low-density lipoprotein oxidation. Br J Clin Pharmacol 1997;44:94-7.

21. Sub Bagian Perinatologi RSUP Dr. Kariadi. Penatalaksanaan bayi normal. Dalam: Sub Bagian Perinatologi RSUP Dr. Kariadi. Prosedur tetap pelayanan perinatal risiko tinggi RSUP Dr. Kariadi Semarang, tingkat I-III. Semarang: RSUP Dr. Kariadi; 2005.h.1-2.

22. Maisels MJ. Jaundice. In: Avery GB, Fletcher MA, Mac Donald MG, penyunting. Neonatology, pathophysiology $\&$ management of the newborn. Edisi ke-5. Baltimore: Lippincot Williams \& Wilkins; 1999.h.765-819.

23. Abdul-Razzak KK, Nusier MK, Obediat AD, Salim AM. Antioxidant vitamins and hyperbilirubinemia in neonates. Ger Med Sci 2007;5:1-7.

24. Mohan SK, Priya V. Status of lipid peroxidation, glutathione, ascorbic acid, vitamin $\mathrm{E}$ and antioxidant enzymes in neonatal jaundice patients. J Clin Diag Res 2008;3:827-32.

25. Necheles TF, Rai US, Valaes T. The role of haemolysis in neonatal hyperbilirubinaemia as reflected in carboxyhaemoglobin levels. Acta Paediatr Scand 1976;65:361-7.

26. Cross CE, Halliwell B, Borish ET, Pryor WA, Ames BN, Saul RL, dkk. Oxygen radicals and human disease. Ann Intern Med 1987;107(4):526-45.

27. Robles R, Palomino N, Robles A. Oxidative stress in the neonate. Early Hum Dev 2001;65 Suppl:S75-81.

28. Yigit S, Yurdakok M, Kilinç K, Oran O, Erdem G, Tekinalp G. Serum malondialdehyde concentration in babies with hyperbilirubinaemia. Arch Dis Child Fetal Neonatal Ed 1999;80:F235-7.

29. Dani C, Martelli E, Bertini G, Pezzati M, Filippi L, Rossetti M, dkk. Plasma bilirubin level and oxidative stress in preterm infants. Arch Dis Child Fetal Neonatal 
Ed 2003;88:F119-23.

30. Bracci R, Buonocore G, Talluri B, Berni S. Neonatal hyperbilirubinemia. Evidence for a role of the erythrocyte enzyme activities involved in the detoxification of oxygen radicals. Acta Paediatr Scand 1988;77:349-56.

31. Percival M. Antioxidants. Clin Nutr Insights 1998;Nut031 1/96 Rev 10/98:1-4.

32. Niki E, Yamamoto Y, Komuro E, Sato K. Membrane damage due to lipid oxidation. Am J Clin Nutr 1991;53(1 Suppl):201S-5S.

33. Strain JJ, Mulholland CW. Vitamin C and vitamin E - synergistic interactions in vivo? EXS Journal 1992;62:419-22.

34. Bast A, Haenen GR, Doelman CJ. Oxidants and antioxidants, state of art. Am J Med 1991;91(3C):2S$13 S$. 